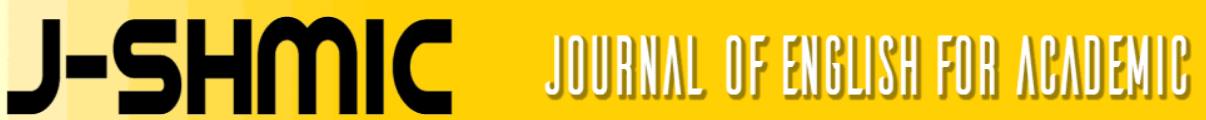

\section{Contribution of Reading Interest and Guessing Words Meaning in Context Mastery Toward Reading Comprehension}

\author{
Samsul Amri \\ Islamic University of Indragiri \\ email:mr.amri85@gmail.com
}

\begin{abstract}
This study investigates the correlative aspects among three variables; reading interest, guessing words meaning in context mastery, and reading comprehension. It comes up in analyzing the theories and results of some studies that reading interest and guessing words meaning in context mastery would or would not contribute to reading comprehension. It indicates this concern is being confered now on. To achieve this purpose, it is designed as correlational study, where it took the fourth semester students English Study Program of FKIPIslamic University of Indragiri as sample. Two kinds of instrumentations were utilized; questionnaire and tests. While analyzing the data, the researcher used Pearson Product Moment statistical analysis. Its findings reveal that the correlation coefficient was $r_{x y}=0.817$, which was categorized as high correlation. Hypothesis testing aslo determined that critical value of $r_{x y}$ was greater than critical value of $t_{\text {table }}$ in significant level $5 \%(0.817>0.374)$. It was evidently proven that there was a positive correlation among the students' reading interest and guessing words meaning in context mastery toward reading comprehension. Then the determination coefficent is 0.667 , which means the students' reading interest and guessing words meaning in context mastery contribute $66.7 \%$ toward reading comprehension. It infers that who wants to have better in reading should have better in reading interest and guessing words meaning in contexts mastery.
\end{abstract}

Key words: Reading Interest, Guesssing Words Meaning in Context, Reading Comprehension.

\section{Kontribusi Minat Membaca dan Kemampuan Menerka Makna Kata Berdasarkan Konteks Terhadap Keterampilan Membaca}

\begin{abstract}
Abstrak
Penelitian menguji aspek korelatif dari tiga variabel yakni minat baca, kemampuan menebak makna kata dalam konteks, dan pemahaman membaca. Hal ini dilatar belakangi hasil analisis teori dan penelitian terdahulu yang berkaitan dengan minat baca dan kemampuan menebak makna kata berkontribusi atau tidak terhadap pemahaman membaca. Ini bermakna bahwa isu tersebut masih terus didiskusikan sekarang dan akan datang. Untuk mencapai tujuan tersebut, jenis Penelitian Korelasi digunakan. Dimana seluruh mahasiswa semester empat Prodi Pendidikan Bahasa Inggris FKIP-UNISI Tembilahan sebagai sampel. Dalam mengumpulkan data, dua jenis instrumen digunakan; angket dan tes. Sedangkan
\end{abstract}


dalam menganalisa data, peneliti menggunakan rumus analisis statistik Pearson Product Moment. Hasil penelitian menunjukkan bahwa nilai korelasi $r_{x y}=0,817$, dikategorikan korelasi yang tinggi. Uji hipotesis juga menunjukkan bahwa nilai $r_{x y}$ lebih besar dari nilai $r_{t a b l e}$ pada taraf signifikan $5 \%(0.817>0.374)$. Ini jelas membuktikan bahwa terdapat korelasi postif antara minat baca siswa, kemampuan menebak makna kata dalam konteks terhadap pemahaman membaca. Selanjutnya, nilai determinasi 0.667, yang berarti bahwa minat baca dan kemampuan menebak makna kata dalam konteks berkontribusi $66.7 \%$ terhadap pemahaman membaca. Ini bermakna bahwa seseorang yang berkeinginan untuk memiliki pemahaman membaca yang baik seharusnya memiliki minat baca dan kemampuan menebak makna kata dalam konteks yang baik pula.

Kata Kunci: Minat Baca, Menebak Makna Kata dalam Konteks, Pemahaman Membaca.

\section{INTRODUCTION}

Reading, one of language skills, cavorts principal role in students' activities because through reading they enable to gain information from printed or online sources. According to Alyousef (2005) and Murcia (2001) reading is an interactive process between a reader and a text. It is a set of skills that incorporates engaging sense and getting meaning from the printed words. In this process, the reader interacts dynamically with the text as he strives to gain details and various knowledge. It infers in the reading activity, he does not only adjust on exposing the words level, but it also grasps the details on the text. Principally, the primary objective of reading is to grasp of what is being read.

There are some skills and components in comprehending the texts. Ghanni (2002) expounds there are five skills in reading comprehension activity; percieving the meaning of the words in context, understanding the rule and the meaning of non-idiomatic phrases and infinitive phrases, discerning the sentence meaning through systematic structure theory, recognizing rhetorical structure, and reading critically by understanding the purpose of the writer, making inference, getting conclusion, evaluating the writer resources, and evaluating the written type and the writers' tone. Then Sharpe, P.J. (2009) mentions five components of reading comprehension; finding detail information which requires the readers to scan specific factual, finding main ideas which is what the paragraph develops, recognizing the meaning of certain words which is not familiar by relating the close meaning of unfamiliar words to the text and the topic of the text that is read, identifying references that recognize the references of the words and being able to identify the words to which they refer to was help the readers understand the reading passage, and identifying inference which may be point of view, conclusion or unstated information of the texts.

Moreover, language components have substantial point for 
the language skills. They involve vocabulary, grammar, and pronunciation. Of all language components, vocabulary holds the core in language teaching. Richards and Renandya (2002) argue that vocabulary is a major aspect of language knowledge and outfits the basis for how well learners listen, speak read, and write. It implies that to enrich their language capacity, they must subdue vocabulary.

In reading, for instance, the students will gain impediments in comprehending the texts if they do not recognize the meaning of words in the texts. In relation to the objective of teaching reading in tertiary level, which outfits them to attain the knowledge from books, journals, articles, magazines and other sources which are written in English, lecturers should look upon their vocabulary dominance.

In line this case, some problems come up in reading process. The readers, in reading the texts, need to call to mind the terms meaning in the text, but in reality they do not know all English words list. It seems so silly if they always look up dictionary while reading the texts. Thus, they should enable to guess the terms meaning through context. Supporting this point, Robinson (2010) if English is your second or foreign language, when you read, you may find many understandable terms. It is not compatible to check every new terms in the dictionary. If it is so, your reading is interrupted. You lose the points. Also, you do not retain the new terms. When you read them again, you often just have to look them up again in the dictionary.
A better way to read is to guess what most of the new terms mean. Guessing words meaning in context is one of useful skills where the learners enable to use it inside and outside classroom. It is an impulsive technique to learn language. They may not guess the exact meaning the first time they see a new term, yet they can attain a common sense of terms. In the same point, it is considered a subskill of reading, where the significance of vocabulary learning is unquestionable. Moreover, learning from context has long been desirable by lecturers and many lecturers have found learning from context to be effective (Nation, 2001; Thornbury, 2002).

Nation and Coady (1988) as quoted by Mart (2012) suggests five steps strategy for guessing from context; (a) finding the part of speech of the unrecognized word, (b) looking at the immediate context of the unknown word and simplifying this context if necessary, (c) looking at the wider context of the unknown word. This means looking at the relationship between the clause containing the unknown terms and surrounding clauses and sentences, (d) guessing the meaning of the unrecognized term, and (e) checking that the guess is correct.

Then, there are four common types of context clues (1) Examples, Examples may suggest the meaning of an unknown word. To understand how this type of clue works, "The adverse effects of this drug, including dizziness, nausea, and headaches, have caused it to be withdrawn from the market." The examplesdizziness, nausea, and headacheshelped you figure out that the word 
adverse means "harmful."

Synonyms, a word that means the same or almost the same as the unknown word, may appear anywhere in a passage to provide the same meaning as the unknown word. For instance, "Fresh garlic may not enhance the breath, but it certainly does improve spaghetti sauce." In the sentence, the synonym given should have helped you understand the meaning of the word in italics: enhance means "improve." (3) Antonym, a word that means the opposite of another word, is also a useful context clue, which are often signaled by words and phrases such as however,but, yet, on the other hand, and in contrast. For example, "Many people have pointed out the harmful effects that a working mother may have on the family, yet there are many salutary effects as well." Salutary means "beneficial." (4) General Sense of the Sentence or Passage, it takes a bit more detective work to puzzle out the meaning of an unfamiliar word. In such cases, you must draw conclusions based on the information given with the word. Asking yourself questions about the passage may help you make a fairly accurate guess about the meaning of the unfamiliar word. For instance, "A former employee, irate over having been fired, broke into the plant and deliberately wrecked several machines." (What would be the employee's state of mind?) Irate means "very angry." To sum up, to save time when reading, the readers should try to figure out the meanings of unfamiliar words by looking at their context - the words surrounding them.
Additionally, reading process results do not only influence by the language componets itself, but also from other factors. There are some influencing factors of learning achievement which involve reading skill. As Purwanto (1986) said (1) Internal factor is the factor which comes from the students' inherent condition for instance: interest, intelligent, attention, motivation and attitude. (2) External factor is the factor which is from outside, for instance: family, school, friends, teacher and society. For the school itself there are some factors which also affect the learning activity, such as curriculum lecturers, motivation, education material of text book, and others.

Concerning the theories above, one of factors that also has essential point in reading is internal factor that is reading interest. As in generally known, it is a motivational variable that involves not only the emotions but also the intellect (Hidi, Renninger, \& Krapp, 2004). Having interest in reading is critical due to having that, the students will do reading gladly, thus they will attain benefits from what they read. The successfull reading is fundamental and is most neeeded since it is the primary device in learning activity. All subjects such as science, linguistic, social and even mathematics need the ability and interest in reading. Henning in Brantmeier (2006) surveys the Egyptian ESL students and concludes that interest is one of factors that affects in acquisition of language. So far, there is no conclusive evidence about the effect of interest on foreign language reading comprehension. 
McKenna (1994), in his study on the relationship between interest and language learning, his finding showed positive correlation between them.

Eidswick (2009) categorizes interest as situational interest, individual interest and topic interest. Individual interest subsumes the readers' preferences for certain text topics or subject matter, and this interest exists before reading a particular text. Situational interest refers to interest caused by situational factors, such as the text and test; a particular situation can influence situational interest, and is therefore not enduring. Topic interest refers to interest prompted by a certain topic or theme. It appears to share qualities of both situational and individual interest with contributions of either depending on individuals' knowledge, experiences and the perceived value of a topic. Moreover, Crawley and Mountain (1995) identified six factors that influenced the development of children's interests; previous experience, self-concept, values, understandable subject, the level of pressure involvement, and the complexity of subject material.

The review of theories and the facts above made the researcher assumed that reading interest and knowing terms meaning mastery have an essential and special place in the reading comprehension. Therefore, the researcher is interested in investigating the effect of students' reading interest and guessing terms meaning in context mastery and their reading comprehension.

To prove the assumtion, some previous studies have been reviewed in relating to the contribution of list words mastery and reading interest toward reading comprehension. Furqon (2013) investigated correlation between students' vocabulary mastery and their reading comprehension. The findings showed that there was a strong correlation between two variables. Moreover, Susanto, et.al. (2014) have undertaken a study on determining the correlation between students' reading interest and students' reading comprehension . Based on the results of the research it could be implied that there was correlation between students' reading interest and their reading comprehension. By having high reading interest, the students enable to comprehend the texts better than those who have low interest. Then Dewi (2007) inquired the relationship among students' interest in reading scientific essay, scientific vocabulary mastery and their reading comprehension achievement. The results revealed that both independent variables had significant correlation to dependent variable. Briefly, those findings have shown that the students' mastery in vocabulary, includes guessing vocabulary meaning in context, and reading interest could contribute to the results of reading comprehension.

Accordance with the curriculum English Study Program FKIP-UNISI Tembilahan, the students have taken on reading classes. Especially, for the fourth semester students, they have joined on Reading IV course, which concerns on reading scientific reading sources such as journal, articles, and research reports. They also have been trained and guided in doing reading comprehension for TOEFL test. Moreover, it assumed that their 
predicting vocabulary meaning in context mastery was in wide range and their reading interest was in varies greatly. Therefore, the reseacher came to the final statement that it needed to investigate and retest the previous studies findings and theories that guessing word meaning in context mastery and reading interest have correlation on reading comprhension. Thus the fundamental aims of the study were to determine (1) how the students' reading interest, guessing word meaning in context mastery, and reading comprehension are; (2) whether and to what degree the correlation and contribution between the reading interest and reading comprehension; (3) whether and to what degree the correlation and contribution between the mastery in guessing word meaning in context and reading comprehension; (4) whether and to what degree the correlation and contribution among the reading interest and mastery in guessing word meaning in context toward reading comprehension.

\section{METHOD}

The correlational research design is occupied to settle the research expectation. It involves collecting data to restrict whether and to what degree a relationship endures between two or more quantifiable variable. Moreover, the level of relationship is expressed as correlation coefficient. It outfits a prospect to predict scores and explain the relationship among variables. If a relationship occurs among the variables, it implies that scores within a certain range on one variable are associated on the other variables. (Gay and Airasian, 2000:321; Creswell, 2005).

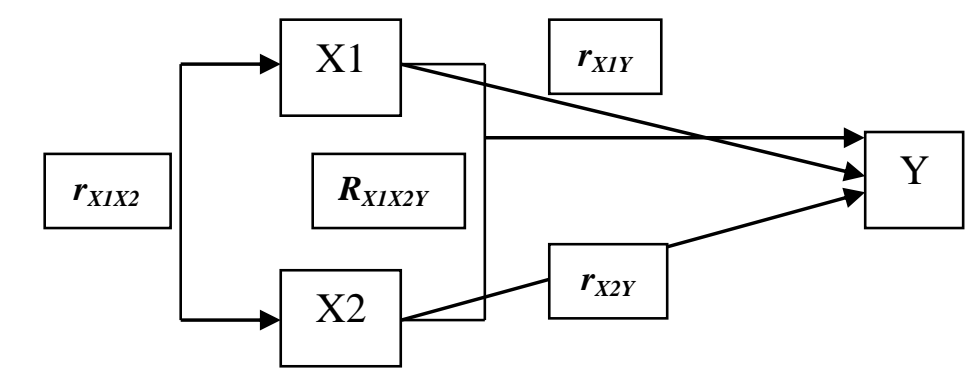

Figure 1. Conceptual of Reasearch Methodology

The subject involved thirty the fourth semester students of English Study Program FKIP-Islamic University of Indragiri Tembilahan, Indonesia, They attended reading IV course. They were selected from one equal intact class by using total sampling technique, which all samples are selected from all desired population (Riduwan: 2005:64).
Two kinds of instrumentation devices were used: Test: It purposed to determine how well the students' guessing words meaning in context mastery and their reading skill. The indicators of guessing word meaning in context involved predicting the terms meaning on synonym, antonym, example, and general sense of the sentence or passage. Meanwhile, the assessed aspects for 
reading skill were finding main idea, identifying references, making inference, identifying unknown terms, and finding detail information. Questionnaire. It aimed at finding out the students' reading interest. It was constructed in Liker scale form, which has five alternative choices (Strongly Agree (5), Agree (4), Neutral (3), Disagree (2), and Strongly Disagree(1)). The indicators included feeling like in reading, focusing on reading, using time on reading, motivation of reading, and reading efforts.

In analyzing the students' guessing terms meaning in context

Table 1. The Interpretation of Correlation Coefficient

\begin{tabular}{|l|c|}
\hline \multicolumn{1}{|c|}{$\mathbf{r}_{\mathbf{x y}}$} & Interpretation \\
\hline $0.00-0.20$ & Very low Correlation \\
\hline $0.21-0.40$ & Low Correlation \\
\hline $0.41-0.70$ & Moderate Correlation \\
\hline $0.71-0.90$ & High Correlation \\
\hline $0.91-1.00$ & Very High Correlation \\
\hline
\end{tabular}

\section{FINDINGS AND DISCUSSION}

\subsection{Findings}

It displays the research findings which cover research variable description, reading interest results, guessing meaning words in context mastery results, reading comprehension results, normality testing, linearity testing, correlation coefficient, and hypothesis testing. and reading comprehension test, the researcher utilized descriptive statistics analysis. Then the students' reading interest was analyzed by using Likert Scale analysis. Furthermore, in investigating the correlation coefficient among variables, he used statistical analysis of Pearson Product Moment correlation, multivariate correlation analysis, and SPSS application, and to obtain the level of correlation coefficient among variables, Sudijono (2004:193) proposes the following classification: 


\begin{tabular}{|l|l|l|l|l|l|l|l|l|l|l|}
\hline $\begin{array}{l}\text { Reading Interest } \\
\text { Valid N } \\
\text { (listwise) }\end{array}$ & 30 & 14.40 & 58.40 & 72.80 & 67.5933 & 4.02834 & -.448 & .427 & -.736 & .833 \\
\hline
\end{tabular}

The empirical data above inform that the minimum score was 58.40 which was classified as enough category, and the highest score was 72.80 which was in strong or high category. It implies that the students' reading interest was not so different each other. It was supported through the results of the range of the students' score, 14.40, and deviation standard, 4.03. Moreover, it determines if the data was normally distributed, the researcher used Skewness and Kurtosis analysis where the criteria as follows:

a. The data is distributed normally if the values of statistic is devided by the value of standard error is ranging between -2 to 2 .

b. The data is not distributed normally if the values of statistic is devided by the value of standard error is excluded ranging between -2 to 2 .

Obviously, it could be found that the Skewness score; statistic ($0.448)$ and standard error (0.427). After analysing the score it was gained that $(-0.448 / 0.427=-1.049)$, meanwhile, it could be gained that the Kurtosis scores; statistic (-0.736) and standard error (0.833). After computing the score it was gained that $(-0.736 / 0.833=-0.883)$. The final statement was that the Skewnes and Kurtosis analysis scores were ranging between -2 to 2 . In other words, the data were distributed normally.

Then the classification of the students' reading interest could be displayed in the following table:

Table 3. The Classification of Students' Reading Interest

\begin{tabular}{|c|c|c|c|c|}
\hline \multirow{2}{*}{ No. } & \multicolumn{2}{|c|}{ Classification } & \multirow{2}{*}{ Frequency } & \multirow{2}{*}{$\begin{array}{c}\text { Percentage } \\
(\%)\end{array}$} \\
\hline & Interval Score & Level & & \\
\hline 1 & $81-100$ & Very High & 0 & 0 \\
\hline 2 & $61-80$ & High & 29 & 96.67 \\
\hline 3 & $41-60$ & Enough & 1 & 3.33 \\
\hline 4 & $21-40$ & Low & 0 & 0 \\
\hline 5 & $00-20$ & Very Low & 0 & 0 \\
\hline Total & & & 30 & $100 \%$ \\
\hline
\end{tabular}

It might be seen that there was none of students whose ability very high, low and very low. then, there were 29 students $(96.67 \%)$ which were considered high. next, 1 student $(3.33 \%)$ were placed enough. the mean score of students reading interest was 67.59, which was categorized in the interval high level. It implied that the students had high reading interest in English texts. 
The Results of Students' Guessing Words Meaning in Context Mastery.

The details of guessing words meaning in context were collected from desired subjects. The students' scores of guessing words maeaning in context capability might be displayed as follows:

Table 4. Descriptive Statistics of Guessing Words Meaning in Context

\begin{tabular}{|c|c|c|c|c|c|c|c|c|c|c|}
\hline & $\mathrm{N}$ & Range & $\begin{array}{c}\text { Minimu } \\
\mathrm{m}\end{array}$ & $\begin{array}{c}\text { Maximu } \\
\mathrm{m}\end{array}$ & Mean & $\begin{array}{c}\text { Std. } \\
\text { Deviatio } \\
\mathrm{n}\end{array}$ & \multicolumn{2}{|c|}{ Skewness } & \multicolumn{2}{|c|}{ Kurtosis } \\
\hline & $\begin{array}{c}\text { Statisti } \\
\text { c }\end{array}$ & \begin{tabular}{|c} 
Statisti \\
$\mathrm{c}$
\end{tabular} & Statistic & Statistic & $\begin{array}{c}\text { Statisti } \\
\text { c }\end{array}$ & Statistic & $\begin{array}{c}\text { Statisti } \\
\mathrm{c}\end{array}$ & $\begin{array}{l}\text { Std. } \\
\text { Error }\end{array}$ & $\begin{array}{c}\text { Statisti } \\
\mathrm{c}\end{array}$ & \begin{tabular}{|l} 
Std. \\
Error
\end{tabular} \\
\hline $\begin{array}{l}\text { Guessing Word } \\
\text { Meaning in } \\
\text { Context } \\
\text { Valid N (listwise) }\end{array}$ & 30 & 30.90 & 56.60 & 87.50 & $\begin{array}{r}70.503 \\
7\end{array}$ & 8.59814 & .136 & .427 & -.413 & .833 \\
\hline
\end{tabular}

The data above presents the information that the number of the respondents were 30 students. The minimum point was 56.60 which was classified as low level, and the maximum point was 87.50 which was in very high level. Supported by the range of the students' score was 30.90 , and the deviation standard was 8.598. It inferred that the students' prosperity in predicting terms meaning through context was distributed widely. Moreover, normality testing of the data was needed by considering the Skewness and Kurtosis analysis where the criteria as follows:

a. The data is distributed normally if the values of statistic is devided by the value of standard error is ranging between -2 to 2 . b. The data is not distributed normally if the values of statistic is devided by the value of standard error is excluded ranging between -2 to 2 .

The factual data prove that the Skewness score; statistic (0.136) and standard error (0.427). It was gained that $(0.136 / 0.427=0.318)$. Meanwhile, the Kurtosis scores; statistic (-0.413) and standard error (0.833). It was obtained that ($0.413 / 0.833=-0.495)$. Perfectly, it could be seen that the Skewnes and Kurtosis analysis scores were ranging between -2 to 2 . In short, the data were dispensed normally.

Additionally, the students' guessing terms meaning in context ability might be proferred in the existing table:

Table 5. Students' Mastery in Guessing Words Meaning in Context

\begin{tabular}{|c|c|c|c|c|}
\hline \multirow{2}{*}{ No. } & \multicolumn{2}{|c|}{ Classification } & \multirow{2}{*}{ Frequency } & $\begin{array}{c}\text { Percentage } \\
(\boldsymbol{\%})\end{array}$ \\
\cline { 2 - 5 } & Interval Score & Level & & 13.4 \\
\hline 1 & $80-100$ & Very High & 4 & 39.9 \\
\hline 2 & $70-79$ & High & 12 & \\
\hline
\end{tabular}




\begin{tabular}{|c|c|c|c|c|}
\hline 3 & $60-69$ & Enough & 10 & 33.3 \\
\hline 4 & $50-59$ & Low & 4 & 13.4 \\
\hline 5 & $00-49$ & Very Low & 0 & 0 \\
\hline Total & & & 30 & $100 \%$ \\
\hline
\end{tabular}

The current data displayed that there were four students $(13.4 \%)$ who got very high level, twelve students $(39.9 \%)$ who were placed in high category, ten students $(33.3 \%)$ who gained enough level, four students $(13.4 \%)$ who obtained low level, and none of them who was labeled in very low level. It proposes that their mastery in guessing words meaning in context were in diverse. Then the mean score of the overall ability was 70.50 which was classified in high level.

\section{The Results of Students' Reading Comprehension}

The existing data of reading comprehension were administrated as the test to the intended respondents. The students' scores of reading capability might be exhibited as follows:

Table 6. Descriptive Statistics of Reading Comprehension

\begin{tabular}{|l|c|c|c|c|c|c|c|c|c|c|}
\hline & $\mathrm{N}$ & Range & $\begin{array}{c}\text { Minimu } \\
\mathrm{m}\end{array}$ & $\begin{array}{c}\text { Maximu } \\
\mathrm{m}\end{array}$ & Mean & $\begin{array}{c}\text { Seviatio } \\
\mathrm{n}\end{array}$ & \multicolumn{2}{|c|}{ Skewness } & \multicolumn{2}{|c|}{ Kurtosis } \\
\cline { 2 - 8 } & Statistic & $\begin{array}{c}\text { Statisti } \\
\mathrm{c}\end{array}$ & Statistic & Statistic & Statistic & Statistic & $\begin{array}{c}\text { Statisti } \\
\mathrm{c}\end{array}$ & $\begin{array}{c}\text { Std. } \\
\text { Error }\end{array}$ & $\begin{array}{c}\text { Statisti } \\
\mathrm{c}\end{array}$ & $\begin{array}{c}\text { Std. } \\
\text { Error }\end{array}$ \\
\hline $\begin{array}{l}\text { Reading } \\
\text { Comprehension } \\
\text { Valid N (listwise) }\end{array}$ & 30 & 24.00 & 60.00 & 84.00 & $\begin{array}{c}70.400 \\
0\end{array}$ & 6.69328 & .310 & .427 & -.360 & .833 \\
\hline
\end{tabular}

The data above provide the information of the students' reading comprehension results, which were taken the reserach subjects. The dejected score was 60.00 which was labeled as enough classification, and the great score was 84.00 which was in very high classification. The range of the students' score was 24.00 , and the deviation standard was 6.693 . They show that the students' reading skill was sufficiently varied. Then, to test the normality of the data, the researcher employed Skewness and Kurtosis analysis the existing criteria as follows:

a. The data is distributed normally if the values of statistic is devided by the value of standard error is ranging between -2 to 2 .

a. The data is not distributed normally if the values of statistic is devided by the value of standard error is excluded ranging between -2 to 2 .

Concerning the data above, it was noticed that the Skewness score; statistic (0.310) and standard error (0.427). It was gained that ($0.136 / 0.427=0.726$ ), and Kurtosis scores; statistic (-0.360) and standard error $(0.833)$. It was attained that ($0.360 / 0.833=-0.432)$. As the result, the Skewnes and Kurtosis analysis scores were in the interval score -2 to 
2. It implies the data were given out normally.
Furtermore, the students' reading comprehension might be presented in the following table:

Table 7. The Classification of Students' Reading Comprehension

\begin{tabular}{|c|c|c|c|c|}
\hline \multirow{2}{*}{ No. } & \multicolumn{2}{|c|}{ Classification } & \multirow{2}{*}{ Frequency } & \multirow{2}{*}{$\begin{array}{c}\text { Percentage } \\
(\%)\end{array}$} \\
\hline & Interval Score & Level & & \\
\hline 1 & $80-100$ & Very High & 4 & 13.4 \\
\hline 2 & $70-79$ & High & 9 & 29.98 \\
\hline 3 & $60-69$ & Enough & 17 & 56.62 \\
\hline 4 & $50-59$ & Low & 0 & 0 \\
\hline 5 & $00-49$ & Very Low & 0 & 0 \\
\hline Total & & & 30 & $100 \%$ \\
\hline
\end{tabular}

It was obviously found that there were four students (13.4\%) who got very high level, nine students $(29.98 \%)$ who were categorized in high category, seventeen students (56.62\%) who gained enough level, and none of them who was classified in low and very low categories. Overall, their reading comprehension ability was 70.40 which was placed in high level.

\section{Correlation Coefficient between Reading Interest (X1) and Reading Comprehension (Y).}

Two variables tested, reading interest and reading comprehension, were analyzed by using statistical analysis. To determine how close the relationship between them, the researcher used Person Product Moment Correlation (bivariate) analysis.

Table 8. Correlation Coefficient between Reading Interest and Reading Comprehension

\begin{tabular}{|ll|c|c|}
\hline & & Reading Comprehension & Reading Interest \\
\hline $\begin{array}{l}\text { Pearson } \\
\text { Correlation }\end{array}$ & $\begin{array}{l}\text { Reading } \\
\text { Comprehension } \\
\text { Reading Interest }\end{array}$ & 1.000 & .457 \\
\hline Sig. (1-tailed) & $\begin{array}{l}\text { Reading } \\
\text { Comprehension } \\
\text { Reading Interest }\end{array}$ & .457 & 1.000 \\
\hline $\mathrm{N}$ & $\begin{array}{l}\text { Reading } \\
\text { Comprehension } \\
\text { Reading Interest }\end{array}$ & .006 & .006 \\
& & 30 &. \\
\hline
\end{tabular}


The table above presents the correlation coefficient between the students' reading interest and reading comprehension which was 0.457 . It was placed as moderate or enough level. Then, to test the hyphothesis could be seen from the Sig. score with the criteria if the Sig. score >
$0.05, \mathrm{H}_{\mathrm{o}}$ is accepted, $\mathrm{H}_{1}$ is rejected and vice versa. The results shows that the Sig. score was 0.006 . It was clearly determined $0.006<0.05$. In other words, there is significant and positive correlation between reading interest and reading comprehension.

Table 9. Contribution of Reading Interest toward Reading Comprehension

\begin{tabular}{|l|r|r|r|r|}
\hline Model & \multicolumn{1}{|c|}{$\mathrm{R}$} & R Square & $\begin{array}{c}\text { Adjusted R } \\
\text { Square }\end{array}$ & $\begin{array}{c}\text { Std. Error of the } \\
\text { Estimate }\end{array}$ \\
\hline 1 & $.457^{\mathrm{a}}$ & .209 & .181 & 6.05909 \\
\hline
\end{tabular}

a. Predictors: (Constant), Reading Interest

It was determined that $\mathrm{R}$ square score (the contributions of reading interest toward reading comprehension) was 0.209 ; it means that variable reading interest contributed $20.9 \%$ toward reading comprehension, and $79.1 \%$ is affected by other variables. In a nutshell, the language learners who intent to be better in reading comprehension should have high interest in reading.

\section{Correlation Coefficient between Guessing Words Meaning in Context Mastery (X2) and Reading Comprehension (Y).}

The variables observed, guessing words meaning in context mastery and reading comprehension, were dissected by using statistical analysis of Person Product Moment Correlation. The results were in the current table:

Table 10. Correlation Coefficient between Guessing Word Meaning in Context Mastery and Reading Comprehension

\begin{tabular}{|ll|c|c|}
\hline & $\begin{array}{c}\text { Reading } \\
\text { Comprehension }\end{array}$ & $\begin{array}{c}\text { Guessing Word } \\
\text { Meaning in Context }\end{array}$ \\
\hline $\begin{array}{l}\text { Pearson } \\
\text { Correlation }\end{array}$ & $\begin{array}{l}\text { Reading } \\
\text { Comprehension } \\
\text { Guessing Word } \\
\text { Meaning in Context }\end{array}$ & 1.000 & .813 \\
\hline Sig. (1-tailed) & .813 & 1.000 \\
& $\begin{array}{l}\text { Reading } \\
\text { Guesprehension } \\
\text { Meaning in Context }\end{array}$ & .000 & .000 \\
\hline
\end{tabular}




\begin{tabular}{|l|c|c|}
\hline $\mathrm{N} \quad$ & 30 & 30 \\
Reading & 30 & 30 \\
Comprehension & & \\
\hline
\end{tabular}

Referring the empirical data above, it was gathered the correlation coefficient between the students' guessing word meaning in context and reading comprehension whic was 0.813. It was implied as high level. Then, to examine the hyphothesis might be seen from the Sig. score with the criteria if the Sig. score >
$0.05, \mathrm{H}_{\mathrm{o}}$ is accepted, $\mathrm{H}_{1}$ is rejected and vice versa. The data inform that the Sig. score was 0.000 . It was perfectly discovered $0.000<0.05$. Consequently, there is significant and positive correlation between mastery in guessing word meaning in context and reading comprehension.

Table 11. Contribution of Guessing Words Meaning in Context Mastery toward Reading Comprehension

\begin{tabular}{|c|c|c|c|c|}
\hline Model & $\mathrm{R}$ & $\mathrm{R}$ Square & Adjusted R Square & Std. Error of the Estimate \\
\hline 1 & $.813^{\mathrm{a}}$ & .662 & .650 & 3.96256 \\
\hline
\end{tabular}

a. Predictors: (Constant), Guessing Word Meaning in Context

It was settled that $\mathrm{R}$ square score (the contributions of guessing words meaning in context mastery toward reading comprehension) was 0.662 ; which infers that variable guessing words meaning in context mastery granted $66.2 \%$ toward reading comprehension, and $33.8 \%$ is stired by other aspects. To sum up, those language learners who propose to have compatible reading skill should have compatible mastery in guessing words meaning in context.
Correlation Coefficient among Reading Interest (X1) and Guessing Words Meaning in Context Mastery (X2) toward Reading Comprehension (Y).

All variables studied; reading interest, guessing words meaning in context mastery and reading comprehension were analyzed by employing multivariate statistical analysis.

Table 12. Correlations Coefficient among Reading Interest, Guessing Word Meaning in Context and Reading Comprehension

\begin{tabular}{|c|c|c|c|c|}
\hline Model & $\mathrm{R}$ & R Square & Adjusted R Square & Std. Error of the Estimate \\
\hline 1 & $.817^{\mathrm{a}}$ & .667 & .642 & 4.00370 \\
\hline
\end{tabular}

a. Predictors: (Constant), Reading Interest, Guessing Word Meaning in Context 
Referring the factual data above, it was gathered the correlation coefficient among the variables investigated was 0.817 . It was labeled as high classification. It was restricted that $\mathrm{R}$ square score (the contributions of reading interest, mastery in guessing words meaning in context toward reading comprehension) was 0.667 ; it hits that variable reading interest and guessing words meaning in context mastery provided $66.7 \%$ toward reading comprehension, and $33.3 \%$ is determined by other components. Furthermore, the hyphothesis testing could consider from the Sig. score with the criteria if the Sig. score > $0.05, \mathrm{H}_{\mathrm{o}}$ is accepted, $\mathrm{H}_{1}$ is rejected and vice versa.

Table 13. Anova Score of Hyphotesis Testing

\begin{tabular}{|ll|c|c|c|c|c|}
\hline \multicolumn{1}{|c|}{ Model } & Sum of Squares & df & Mean Square & F & Sig. \\
\hline 1 & Regression & 866.400 & 2 & 433.200 & 27.025 & $.000^{\mathrm{a}}$ \\
& Residual & 432.800 & 27 & 16.030 & & \\
Total & 1299.200 & 29 & & & \\
\hline
\end{tabular}

a. Predictors: (Constant), Reading Interest, Guessing Word Meaning in Context

b. Dependent Variable: Reading Comprehension

The research finding shows that the Sig. score was 0.000 . It was obviously seen $0.000<0.05$. In other words, there is significant and positive correlation among students' reading interest, guessing word meaning in context mastery and reading comprehension. It presumes the language learners who tend to be better in reading comprehension should have congruous reading interest and guessing words meaning in context mastery.

\subsection{Discussion}

The data analysis description results has shown that it was gathered some findings that need to be discussed. Discussion means the researcher discusses the research findings with the previous researches which have been conducted by other researchers. Some points that should be discussed were how the relationship and the contribution among results of reading interest, guessing words meaning in context mastery, and reading comprehension.

Firstly, it related to the language learners' reading interest. It revealed that most of them were classified into high level (96.67\%). It indicated they had great interest in reading English texts. Moreover, the correlation coefficient between the reading interest and reading comprehension was 0.457 , which was labeled in sufficient level. Then determination coefficient was $20.9 \%$ as the contribution of the reading interest toward reading comprehension. Even the score of correlation and determination were not high enough, but after testing the hyphothesis was proven that there was significant and positive correlation between both variabels. To support these results, the previous study was conducted by Susanto, et.al (2014) who investigated the 
correlation between reading interest and reading comprehension at secondary school in Pungur Indonesia. The results of this research showed that the correlation coefficient was 0.673 and the coefficient influences value of both variables was 0.434 . It was shown when the students got high score in interest score; they also got high score for their reading comprehension. Moreover, Gultom, et.al (2014) inquired the correlation between reading interest and reading comprehension ability of the third year students at the English Department of Bung Hatta University. He found that the value of $r_{\text {observed }}$ of this research was 0.78 , while the value of $r_{\text {table }}$ with level significant 0.05 and degree of freedom $(\mathrm{df}=\mathrm{n}-2)$ was 0.362 . It implies that $r_{\text {observed }}$ was higher that $r_{\text {table }}(0.78>0.362)$. Therefore, the alternative hypothesis which was there is significant correlation between the students' interest and reading comprehension was accepted. Thus, to increase the students' reading comprehension, they have to be more interest in reading. In conclusion, there was correlation between reading interest and reading comprehension. By having high reading interest, they were able to read better than those who have low interest.

Secondly, it was relevant with the students' mastery in guessing words meaning in context. It was found that their mastery in guessing words maening in context was classified as high level by supporting the mean score 70.50. Then the correlation coefficient was 0.813 , which was categorized as high correlation, and the determination coefficient was 0.662 , which inferred the students' guessing words meaning in context mastery donated $66.2 \%$ toward the students' reading comprehension. The hyphothesis testing has proven that both variables had meaningful and positive correlation. To support these results, the relevant studies have proposed by Anjomshoa (2014) her study revealed that there is a poistive effect between vocabulary knowledge and reading comprehension for $\mathrm{EFL}$ learners. It was in the same argument with Sedita (2005) who states that vocabulary knowledge is crucial in reading comprehension and determining how well students are in comprehending the texts. In the regard to this matter, her study attempted to determine the relationship between students' reading comprehension and their vocabulary mastery.

Thirdly, it concernned on the students' correlation among reading interest, mastery in guessing words meaning in context and reading comprehension. After computing and analyzing the data, the researcher found that the correlation coefficient among those variables was 0.817 , which was ranging in high category. Moreover, the determination coefficient was 0.667 . It indicates that the students' reading interest and mastery in guessing words meaning in context toward their reading comprehension was $66.7 \%$. The results of hyphothesis testing indicated that there is significant and positive correlation among the variables. These reserach findings were relevant with the previous studies such as Widyastuti (2014) 
who studied the same variables. The results show that there is a positive correlation among reading interest, vocabulary mastery, and reading comprehension $(\mathrm{Ry} 12=0.5604$ and $\mathrm{Fo}=18,48>\mathrm{Ft}=3.32)$. The result of the study shows that reading interest and vocabulary mastery are predictors which give a contribution to reading comprehension as many as $56,04 \%$. So, both reading interest and vocabulary mastery are one of the important factors that should be considered in improving reading comprehension. Other researches have been undertaken by Nurshohifah (2014) and Faliyanti (2015) who aslo examined the contribution of reading interest, vocabulary mastery toward reading comprehension of descriptive text. The results revealed that there is a positive relationship among $\mathrm{X}_{1}, \mathrm{X}_{2}$ and $\mathrm{Y}$ variables all together. It indicated that knowing words meaning is one aspect in reading process. By having plenty of words list, the students will be easier in comprehending the passages. The interest in English provides effect of the students mastery in English. Before starting to read, they are must be interested in English first. Reading is one of language skills which is crucial for them, since through reading they can attain information from the passages.

To sum up, the variables investigated have meaningful and positive correlation eah others, and the independent variables contributed positively toward the dependent variable.

\section{CONCLUSION}

The accomplished data as the requirement and the approval of the research hypothesis were about the relationship among reading interest, guessing word meaning in context mastery and reading comprehension. Some points could be concluded that there is a positive relationship among the students' reading interest and guessing words meaning in context toward their reading comprehension. In other words, the independent variables $\left(\mathrm{X}_{1}\right.$ and $\left.\mathrm{X}_{2}\right)$ contributed criticaly to the improvement of dependent variable (Y). This implies the students who have high interest in reading and mastery in guessing words meaning in context should be easier to understand the text literally and also interpretatively.

\section{REFERENCES}

Alyousef H.S. (2005). Teaching Reading Comprehension to ESL/EFL Learners. The Reading Matrix. Vol. 5, No. 2. September 2014. Available on

http://www.readingmastrix.co $\underline{\mathrm{m} / \text { article/alyousef/article.pdf. }}$

Anjomshoa, L. (2014). The Effect of Vocabulary Knowledge on Reading Comprehension of Iranian EFL Learners in Kermad Azad University. International Journal on Studies in English Language and Literature (IJSELL). Vol. 2, Issue. 5, pp. 90-95. www.arcjournal.org.

Brantmeier, C. (2006) Toward a Multicomponent of Interest and L2 Reading: Source of interest, Percieved situational 
interest, and comprehension reading in English language. 18 (2), 89-115.

Crawley, S.S. and Maintain, L. (1995). Strategies for Guiding Content Reading. Boston : Allyn and Bacon.

Creswell, J.W. (2005). Educational Research: Planning, Conducting, and Evaluating Quantitative and Qualitative Research $\left(2^{\text {nd }}\right.$ ed). New Jersey : Princide-Hall, Inc.

Dewi, D.K. (2007). The Correlation between the Students' Interest in Reading Scientific Essay, Scientific Vocabulary Mastery, and their Achievement in Reading Comprehension. Thesis. State University of Semarang. Available at: $\underline{\text { lib.unnes.ac.id/16971/1/7125 }}$ 990019.pdf

Eidswick. (2009). The Influence of Interest in Reading Comprehension in EFL Students. Annual Research Report of the Language Center, 12, pp. 12-38. Kwansei Gakuin University.

Furqon, Fajar (2013). Correlation between Students' Vocabulary Mastery and Their Reading Comprehension. Journal of English and Education. 1 (1), pp. 68-80.

Faliyanti, Eva. (2014). The Correlation between Students' Vocabulary Mastery and Their Interest in English toward Reading Comprehension in Descriptive Text at the Second Semester of
Muhammadiyah University of Metro. Premise Journal Vol. 4, No.1, ISSN. 2442$482 x$.

Gay, L.R, and Airasian, P. 2000. Educational Research Competencies for Analysis and Application $\left(6^{\text {th }}\right.$ ed). New Jersey : Princide-Hall, Inc.

Gultom, Ully Arta. et.al. (2014). The Correlation between Reading Interest and Reading Comprehension Ability of the Third Year Students at the English Dept. of Bung Hatta University. Thesis. West Sumatera.

Hidi, S., Renninger, K., Krapp. A. (2004). Interest a Motivational Variable that Combine Affective and Cognitive Functioning Mahwah, NJ: Lawrence Erlbaum Associates.

Mart, C.T. (2012). Guessing the Meaning of Words from Context: Why and How?. International Journal at Applied Linguistics \& English Literature. Vol. 1, No.6, November 2012.

Mc Kenna, M.C. (1994). Toward a Model of Reading Attitude Acquisition. In E.H. Cramen \& M. Castle (Eds). Fortering the Love of Reading: The Effective Domain in Reading Education (pp. 18-40). Newarle, DE: International Reading Association.

Nation, I.S.P. (2001). Learning Vocabulary in Another Language. Cambridge : Cambridge University Press. 
Nurshohifah, Lia. (2014). The Relationship Between Students' Reading Interest, Vocabulary Mastery and Their

Reading Ability on Descriptive Text (A Correlational Study on The Eighth Grade Students in Kecamatan Banjar Pandeglang, Academic Year 2012/2013). A Thesis. UIN Syarifhidayatullah Jakarta. Available at: http://repository.uinjkt.ac.id/d space/bitstream/123456789/2 5144/1/LIA\%20NURSHOHI FAH-FITK.pdf

Purwanto N. (1986) Psikologi Pendidikan. Bandung : Remaja Karya.

Richard J.C and Renandy W.A. (2002). Methodology in Language Teaching. Cambridge : Cambridge University Press.

Riduwan. 2005. Belajar Mudah Penelitian untuk Guru, Karyawan dan Peneliti Pemula. Bandung : Alfabeta.

Robinson, J. (2010). Understanding Vocabulary in Context. Douglas College Learning Centre.

Sedita, J. (2005) Effective Vocabulary Interaction. (online). Available : http//www.keytolireracy.com/ reading comprehension/ effective - vocabularyintruction. pdf
Sharpen, Pamela J. (2009). Baron's Practice Exercises for TOEFL (6th ed). New Delhi : Galgotia Publications pvt.ltd.

Sudijono, Anas. 2004. Pengantar Statistik Pendidikan. Jakarta: PT. Raja Grafindo Persada.

Susanto, E.P, et.al. (2014). The Correlation between Students' Reading Interest and Students' Reading Comprehension. Available at: http://download.

portalgaruda.org/article.php?a rticle $=373042 \& \mathrm{val}=7230 \&$ titl $\mathrm{e}=$ THE $\% 20$ CORRELATION \%20BETWEEN\%20STUDE NTS $\%$ C3\%A2\%E2\%82\%AC $\%$ E2\%84\%A2\%20READIN G\%20INTEREST\%20AND $\% 20$ STUDENTS\%C3\%A2\% E2\%82\%AC\%E2\%84\%A2\% 20READING\%20COMPRE HENSION.

Thornbury, S. (2002). How to Teach Vocabulary. England: Pearson Education Limited.

Widyastuti, Ardhitya. (2016). A Correlational Study on Reading Interest, Vocabulary Mastery, and Reading Comprehension of the Eleventh Grade Students of SMA Negeri 1Karanganyar in the Academic Year of 2014/2015. Thesis. Sebelas Maret University. Available at:

http://abstrak.ta.uns.ac.id/wis uda/upload/K2209009_penda huluan.pdf 